\title{
LITTER DECOMPOSITION OF Acacia caven (Molina) Molina AND Lolium multiflorum Lam. IN MEDITERRANEAN CLIMATE ECOSYSTEMS
}

\author{
Ingrid Martínez G. ${ }^{1}$, Erick Zagal V. ${ }^{*}$, Carlos Ovalle M. ${ }^{2}$, Marie-Madeleine Coûteaux ${ }^{3}$, \\ Neal B. Stolpe ${ }^{1}$, and Natalia Valderrama . $^{4}$
}

\begin{abstract}
The ecosystems of the Mediterranean interior dryland of Chile, dominated by an espinal agroecosystem of Acacia caven (Molina) Molina, show low productivity as a result of soil degradation. The objective of this study was to evaluate litter decomposition of $A$. caven and Lolium multiflorum Lam. in espinal ecosystems: well preserved (Wp) 50 to $80 \%$, typical (Pd) 25 to $50 \%$, and degraded (De) with 10 to $25 \%$ cover. During 420 d and starting in April 2004 until August 2005, weight loss in litter bags and chemical composition (hemicellulose, cellulose, lignin, nonstructural components, ash, N, C, C/N ratio, and P) were determined by using near infrared reflectance spectroscopy (NIRS) and the Van Soest protocol. Weight loss ranged from 31 to $52 \%$ in L. multiflorum and 26 to $40 \%$ in A. caven after 420 d. During the chemical decomposition process of L. multiflorum, cellulose degradation was relevant in the labile phase while lignin was important in the recalcitrant phase. On the other hand, non-structural components and cellulose were degraded in the labile phase and lignin in the recalcitrant stage for $A$. caven. Moreover, both litters improved $\mathrm{N}$ concentration during the decomposition process. Espinal ecosystems with higher canopy cover (Pd and Wp) had a positive influence, and showed early effects during the decomposition process, especially in the De espinal ecosystem, probably because of the microenvironmental conditions it generated. A better knowledge of the dynamics of litter decomposition in ecosystems was achieved by using both techniques: litter bags and NIRS.
\end{abstract}

Key words: canopy cover, weight loss, litter bags, NIRS, principal components.

\section{INTRODUCTION}

The Acacia caven (Molina) Molina espinal (Ovalle et al., 1990 ) is the most important silvopastoral ecosystem in central southern Chile. This species is drought-tolerant with a great recovery ability and good root development (Aronson et al., 2002). Studies have indicated that areas with greater hawthorn hedge cover (around 80\%) are more humid during the hot months, and more vegetation grows in this microenvironment due to lower temperature oscillation. The influence of greater canopy cover increases

\footnotetext{
${ }^{1}$ Universidad de Concepción, Facultad de Agronomía, Av. Vicente Méndez 595, Chillán, Chile. *Corresponding author (ezagal@udec.cl). ${ }^{2}$ Instituto de Investigaciones Agropecuarias INIA, Casilla 246, Chillán, Chile.

${ }^{3}$ Centre National de la Recherche Scientifique, Centre d'Ecologie Fonctionnelle et Evolutive, 1919 Route de Mende, Montpellier Cedex 5, France.

${ }^{4}$ Universidad de Concepción, Facultad de Ingeniería Agrícola, Av. Vicente Méndez 595, Chillán, Chile.

Partial results of this research were presented in VI Congreso Internacional de Ingeniería Agrícola. Chillán, Chile. Enero 2009.

Received: 22 April 2009.

Accepted: 04 September 2009.
}

the herbaceous biomass under it, soil organic C (SOC), and soil $\mathrm{N}$ thus increasing available moisture for plants (Ovalle et al., 2006; Muñoz et al., 2007a). Fresh or partially decomposed litter as a source of organic matter (OM) in degraded ecosystems is positive for restoring them given the increase of biological activity generating conditions for increased productivity and species biodiversity, and helping ecosystem rehabilitation, elasticity, or resilience to natural alterations such as drought (Ovalle et al., 2006; Verdoodt et al., 2009).

Litter decomposition rate, measured by weight loss, is a well-studied physical parameter; however, it should be complemented with studies of changes in distinct C fractions (Melillo et al., 1989). There are three fractions in the chemical decomposition of OM: easily decomposed labile fraction corresponding to rapidly degraded carbohydrates and proteins; structural material with slower decomposition made up of cellulose and hemicellulose which are the most abundant in litter; and resistant material with a high lignin and polyphenol content considered as one of the most relevant fractions and most resistant to degradation (Fioretto et al., 2005; Berg and Laskowski, 2006). Microbial activity plays 
an important role in OM decomposition, as well as in nutrient immobilization and mineralization affected by microclimatic conditions (Ritter and Bjørnlund, 2005). Helped by moisture and temperature, litter decomposition in Mediterranean ecosystems temporarily increases (van Meeteren et al., 2008). Initial litter $\mathrm{N}$ content is important in decomposition since it regulates the first phase ( $\mathrm{Su}$ et al., 2004), lignin concentration is more important in advanced stages with a lower response to temperature changes partly explained by the fact that litter decomposition is more rapid at the beginning (van Meeteren et al., 2008).

Litter bags are a technique used to study decomposition processes where plant material is incubated and monitored over time. Although this method creates a microenvironment, it is easily used to study the dynamics of decomposition in samples of known initial weight which can be recovered in field conditions (McTiernan et al., 2003; Berg and Laskowski, 2006).

Near infrared reflectance spectroscopy (NIRS) is an analytical technique that allows determining chemical constituents in different plant tissues and in the soil with a wide range of concentrations (Gillon et al., 2004; Coûteaux et al., 2005; Schimann et al., 2007). The NIRS technique is rapid and non-destructive with exact and reproducible measurements of chemical components in organic materials (McTiernan et al., 2003).

Few studies have compared the effect of tree or canopy cover on litter decomposition processes in Mediterranean ecosystems which allow evaluating rehabilitation practices where decomposition is fundamental in the nutrient cycle. These processes are influenced by the climatic regulation of shrub-tree canopy cover and the quality of organic material of Chilean Mediterranean espinals. The objectives of this study were to investigate in situ decomposition of distinct origin materials with litter bags, such as Acacia caven and Lolium multiflorum Lam. in ecosystems with three shrub-tree canopy cover densities, and evaluate the chemical transformations of material during the degradation process using NIRS.

\section{MATERIALS AND METHODS}

\section{Experimental site and assay description}

The study was carried out in the Cauquenes Experimental Centre of Instituto de Investigaciones Agropecuarias INIA $\left(35^{\circ} 78^{\prime} \mathrm{S} ; 72^{\circ} 20^{\prime} \mathrm{W}\right)$ located in the interior dryland of the Maule Region. The climate is sub-humid Mediterranean with an annual precipitation of $695 \mathrm{~mm}$. Annual mean temperature is $14.7^{\circ} \mathrm{C}$ with a minimum mean of $4.7^{\circ} \mathrm{C}$ and a maximum of $27^{\circ} \mathrm{C}$ (Del Pozo and Del Canto, 1999). Soils are Alfisols of the Cauquenes and Maule series which have been classified as Ultic Haploxeralfs and Ultic Palexeralfs, respectively (CIREN,
1994; Stolpe, 2006). Ecosystems of low tree density espinals showed $\mathrm{pH}$ of 5.10 and $1.4 \%$ organic $\mathrm{C}$ content while those with greater canopy cover showed $\mathrm{pH}$ of 6.1 and $1.9 \%$ organic C. Ecosystems were representative of the area and classified according to hawthorn hedge cover density: degraded espinal (De) with 10 to $25 \%$, typical espinal (Pd) with 25 to $50 \%$, and well preserved espinal (Wp) with 50 to $80 \%$ canopy cover. Decomposition of two litters was compared, a leguminous shrub A. caven and an annual grass, Italian ryegrass (L. multiflorum). These were put into litter bags (12 cm x $20 \mathrm{~cm}$ x $2 \mathrm{~mm}$ ) in 1-m high cages to prevent damage by grazing animals during the experiment. Acacia caven, $5 \mathrm{~g}$ (dry weight) and $10 \mathrm{~g}$ of L. multiflorum were put separately in the bags. A total of 720 litter bags were needed for two types of litter, three ecosystems with two replicates for each one, and six sampling dates. The experiment started in May 2004 and samples were collected after 60, 120, 180, 250,330 , and $420 \mathrm{~d}$. A total of 120 bags were randomly selected on each sampling date (10 bags from each site and type of material). Samples were manually cleaned of soil contamination with the help of a magnifying glass, oven-dried for $48 \mathrm{~h}$ at $55{ }^{\circ} \mathrm{C}$ to determine dry weight of residual material, ground to $1 \mathrm{~mm}$ (Cyclotec, Perstop Analytical, Höganäs, Sweden), and stored in plastic bags for chemical analysis.

\section{NIRS prediction equations}

Prediction equations were developed based on a European program TROPANDES (Coûteaux et al., 2006) which included material similar to the study and where more than 3500 samples in decomposition were scanned by NIRS (NIR Systems 6500, Perstorp Analytical, Silver Spring, Maryland, USA) (Coûteaux et al., 2005). Spectra of this study were compared with spectra selected in TROPANDES. Extreme spectra (Mahalanobis distance > 3) were considered distant and excluded. The most representative samples were then selected by eliminating similar spectra (Mahalanobis distance < 0.6). The Van Soest protocol (Van Soest and Robertson, 1985) was applied to the selected samples to determine hemicellulose, cellulose, lignin content, as well as nonstructural components.

\section{Chemical analysis of plant material}

The Van Soest technique was applied to the decomposed material to determine neutral detergent fiber (NDF), acid detergent fiber (ADF), and acid detergent lignin (ADL) with successive digestions of neutral and acid detergents with the ANKOM ${ }^{200 / 220}$ fiber analyzer (ANKOM Technology, Fairport, New York, USA). Approximately $1 \mathrm{~g}$ of plant material was weighed in F57 filter bags 
(ANKOM Technology Corporation, Fairport, New York, USA) to obtain three types of fiber residues. The samples of each digestion were then oven-dried for $48 \mathrm{~h}$. NDF is the structural residue that includes hemicellulose (NDF-ADF), cellulose (ADF-ADL), lignin (ADL), and non-structural components (100-NDF) (McTiernan et al., 2003). Ash content was determined by calcination at $660{ }^{\circ} \mathrm{C}$ for $6 \mathrm{~h}$.

Total $\mathrm{C}$ and $\mathrm{N}$, and $\mathrm{C} / \mathrm{N}$ ratio were quantified by dry combustion with an elemental analyzer (Vario MAX CNS, Elementar, Elementar Analysensysteme GMBH, Hanau, Germany). Colorimetry was applied to determine P (Colorimeter Helios Epsilon, Unicam, Berlin, Germany) (Sadzawka, 2006).

In the original incubation material, phenols were measured with a portable digital colorimeter (DR/890, HACH Company, Loveland, Colorado, USA), as well as the previously mentioned components (Table 1 ).

\section{Statistical methodology}

Mass loss (ML) was controlled by two reservoirs: reservoir A corresponding to the initial weight percentage made up of a labile fraction of rapid decomposition over time $t$ (days) with rate $k\left(\mathrm{~d}^{-1}\right)$, a recalcitrant reservoir B that does not decompose and is accumulated and which responds to an asymptotic model: $\mathrm{RW}=\mathrm{Ae}^{-k t}+\mathrm{B}$ where $\mathrm{A}+\mathrm{B}=100$. This model is well-adjusted to initially high decomposition (Dalias et al., 2001; Berg and Laskowski, 2006).

Relationships between analyzed variables were established through principal component analysis (PCA) and correlation coefficients $(\mathrm{p}<0.05)$. ANOVA was carried out $(\mathrm{p}<0.01)$ by the STATISTICA version 6 program (Stat Soft, 2000) to determine the influence of ecosystem covers (E), incubation time (T), and their interaction (E x T) on the decomposition of A. caven.

\section{RESULTS AND DISCUSSION}

\section{Effect of canopy cover on decomposition}

At the end of the measurement period of plant material decomposition, residue was quantified as RW. Final ML in litter decomposition after $14 \mathrm{~m}$ did not show any differences for A. caven among the distinct canopy covers while the Wp-S2 ecosystem was different from the rest of the ecosystems for L. multiflorum. Weight loss as a percentage of initial weight fluctuated between 26 and $40 \%$ in A. caven, and 31 and $52 \%$ in L. multiflorum at the end of the study period (Table $2)$. Decomposition rate $(k)$ in both conditions gave similar results for the three canopy covers. However, the model was not appropriate in A. caven for the De$\mathrm{S} 2$ and $\mathrm{Pd}-\mathrm{S} 1$ ecosystems since the analysis shows that reservoir A is greater than 100 (Table 2) and a constant weight loss is observed for these ecosystems (Figure 1). This can be explained by the heterogeneity of the incubated material, fact which is not observed for L. multiflorum since the model did not show this variability. The model used could explain between 54 and $68 \%$ of the experimental values determined in $A$. caven, and 69 and $87 \%$ in L. multiflorum. Despite the results, it was possible to observe a canopy cover effect trend, especially in L. multiflorum where reservoir A (Table 2) increases with canopy cover. These differences in litter weight loss are probably due to the interaction of various factors such as initial $\mathrm{N}$ content $(0.41$ in $L$. multiflorum and $1.83 \%$ in A. caven), an abundance of lignin and phenols in A. caven (28\% and $53 \mathrm{mg} \mathrm{g}^{-1}$, respectively), and recalcitrant fractions delaying organic matter degradation which are considered as the most important factors in the decomposition process (Berg and Laskowski, 2006).

Table 1. Litter chemical composition before field incubation.

\begin{tabular}{lcc}
\hline & Acacia caven & Lolium multiflorum \\
\hline Fiber and other fractions & & \\
Cellulose, \% & $15 \pm 0.09$ & $37 \pm 1.22$ \\
Hemicellulose, $\%$ & $20 \pm 0.65$ & $31 \pm 0.69$ \\
Lignin, \% & $28 \pm 0.29$ & $7 \pm 0.24$ \\
Non-structural compounds (NS), \% & $37 \pm 0.35$ & $25 \pm 1.57$ \\
Ash, \% & $7 \pm 0.08$ & $8 \pm 0.18$ \\
Phenols, mg g ${ }^{-1}$ & $53.0 \pm 0.01$ & $9.5 \pm 1.11$ \\
Nutrient concentration & & \\
N, \% & 1.83 & 0.41 \\
C, $\%$ & 45.14 & 39.80 \\
C/N ratio & 25 & 97 \\
P, $\%$ & 0.06 & 0.05 \\
\hline
\end{tabular}

\pm standard deviation. 
Table 2. Decomposition rate (k) and weight loss (A) at $\mathbf{4 2 0}$ days for Acacia caven and Lolium multiflorum litter.

\begin{tabular}{|c|c|c|c|c|c|c|}
\hline \multirow[b]{2}{*}{ Ecosystem } & \multicolumn{3}{|c|}{ Acacia caven } & \multicolumn{3}{|c|}{ Lolium multiflorum } \\
\hline & $k$ & $\mathbf{A}$ & $\mathbf{R}^{2}$ & $k$ & $\mathbf{A}$ & $\mathbf{R}^{2}$ \\
\hline & $\mathrm{g} \mathrm{d}^{-1}$ & $\%$ & & $\mathrm{~g} \mathrm{~d}^{-1}$ & $\%$ & \\
\hline De - S1 & $0.0065 \pm 0.0016 \mathrm{~ns}$ & $33.44 \pm 3.31$ & 0.61 & $0.0139 \pm 0.0026 b$ & $30.71 \pm 1.38$ & 0.69 \\
\hline De - S2 & $0.0006 \pm 0.0014 \mathrm{~ns}$ & $115.70 \pm 242.50^{1}$ & 0.53 & $0.0047 \pm 0.0008 \mathrm{~b}$ & $40.04 \pm 3.56$ & 0.82 \\
\hline $\mathrm{Pd}-\mathrm{S} 1$ & $0.0012 \pm 0.0010 \mathrm{~ns}$ & $77.49 \pm 53.06^{1}$ & 0.68 & $0.0150 \pm 0.0022 b$ & $34.00 \pm 1.15$ & 0.78 \\
\hline $\mathrm{Pd}-\mathrm{S} 2$ & $0.0162 \pm 0.0035 \mathrm{~ns}$ & $25.85 \pm 1.19$ & 0.66 & $0.0118 \pm 0.0013 b$ & $41.57 \pm 1.25$ & 0.86 \\
\hline $\mathrm{Wp}-\mathrm{S} 1$ & $0.0030 \pm 0.0014 \mathrm{~ns}$ & $39.81 \pm 11.42$ & 0.54 & $0.0065 \pm 0.0011 b$ & $42.67 \pm 2.84$ & 0.78 \\
\hline $\mathrm{Wp}-\mathrm{S} 2$ & $0.0429 \pm 0.0229 \mathrm{~ns}$ & $32.09 \pm 1.29$ & 0.62 & $0.0129 \pm 0.0014 \mathrm{a}$ & $52.11 \pm 1.38$ & 0.87 \\
\hline
\end{tabular}

De: degraded ecosystem; Pd: typical ecosystem; Wp: well preserved ecosystem; S1: site 1; S2: site 2; \pm standard deviation; $\mathrm{R}^{2}$ : regression coefficient; ns: non significant.

Values with the same letters in the columns are not significant according to Tukey test $(\mathrm{p}<0.05)$.

${ }^{1}$ This value indicates the applied model is not adequate for this site and condition since $\mathrm{A}>100$.

The decomposition process was faster at the beginning ( $0-120 \mathrm{~d})$, especially in L. multiflorum because of the decomposition of the labile fraction (Figure 1). The presence or accumulation of recalcitrant material in A. caven revealed a slower decomposition phase in Mediterranean ecosystems (Reichstein et al., 2002; Su et al., 2004).

Similar studies developed in dense Mediterranean ecosystems showed differences in decomposition after 18 $m$ of litter field incubation (Fioretto et al., 2003). Kim et al. (1996) found greater litter decomposition in ecosystems with greater canopy cover in forestry systems after 2 years of study. Although weight loss was not significant among ecosystems in our study, the observed trend shows that as canopy cover increases, weight loss also increases. Thus, determining only weight loss could not be established as an efficient indicator of the litter degradation process during the study period, and it is better to complement these evaluations with chemical parameters that better explain these changes over time.

\section{Chemical transformations of plant material during degradation process}

Acacia caven. Principal component analysis determined that the first two components (PC1 and PC2) explained $53 \%$ of total variability, and increased to $68 \%$ when the third component (PC3) was included. These three components were selected to analyze the study variables (Table 3). The highest positive correlations for PC1 were found in cellulose content $(r=0.78), C(r=0.75)$, and $C / N$ ratio $(r=0.67)$, whereas high negative correlations for ash $(r=-0.76)$ and non-structural components $(r=-0.73)$ were observed. There was a lower negative correlation with the weight loss variable $(r=-0.51)$ indicating that the litter decomposition process was associated more to the interaction of structural and nutritional variables than to the physical loss of plant material. High negative correlations for PC1 suggest that there was rapid degradation of labile material during the initial decomposition process (Table 3 , Figure 1) due to the fact that these easily degraded compounds are more accessible to microbial attack or lixiviation (Bernhard-Reversat, 1999).

The main constituent of the cell wall of A. caven in its initial stage were non-structural components with a value of $37 \%$ (Table 1), the velocity of litter decomposition is associated with climatic conditions favoring the activity of soil microbial biomass as moisture-in Mediterranean ecosystems particularly associated with precipitation events-(Figure 1) and temperature. As decomposition advances, new and easily degradable soluble components are formed, such as holocellulose (cellulose + hemicellulose) and lignin (McTiernan et al., 2003; Berg and Laskowski, 2006) to increase non-structural components ( $\mathrm{PC} 3, \mathrm{r}=0.61)$. The $20 \%$ variance explained by $\mathrm{PC} 2$ was positively correlated with $\mathrm{N}$ from the residual material $(r=0.91)$ and associated with the concentration increase during the decomposition period (Berg and Laskowski, 2006). Finally, PC3 explained $15 \%$ of the variability where lignin showed a negative correlation $(\mathrm{r}=$ -0.55), and indicated lower transformation of recalcitrant materials, thus demonstrating its resistance to microbial decomposition (Martínez-Yrízar et al., 2007).

It is possible to distinguish a wide variable dispersion in the first component (PC1), but most observations were located in the positive axis in the second component (PC2) (Figure 2). It was observed that weight loss was negatively correlated with the $\mathrm{C} / \mathrm{N}$ ratio, as well as with $\mathrm{C}$ content and ash. The $\mathrm{C} / \mathrm{N}$ ratio in litter decomposition studies decreases during the degradation process because of $\mathrm{C}-\mathrm{CO}_{2}$ loss associated with the metabolism of soil microorganisms while $\mathrm{N}$ (organic) concentration increases in the residual material (Coûteaux et al., 1998; McTiernan 

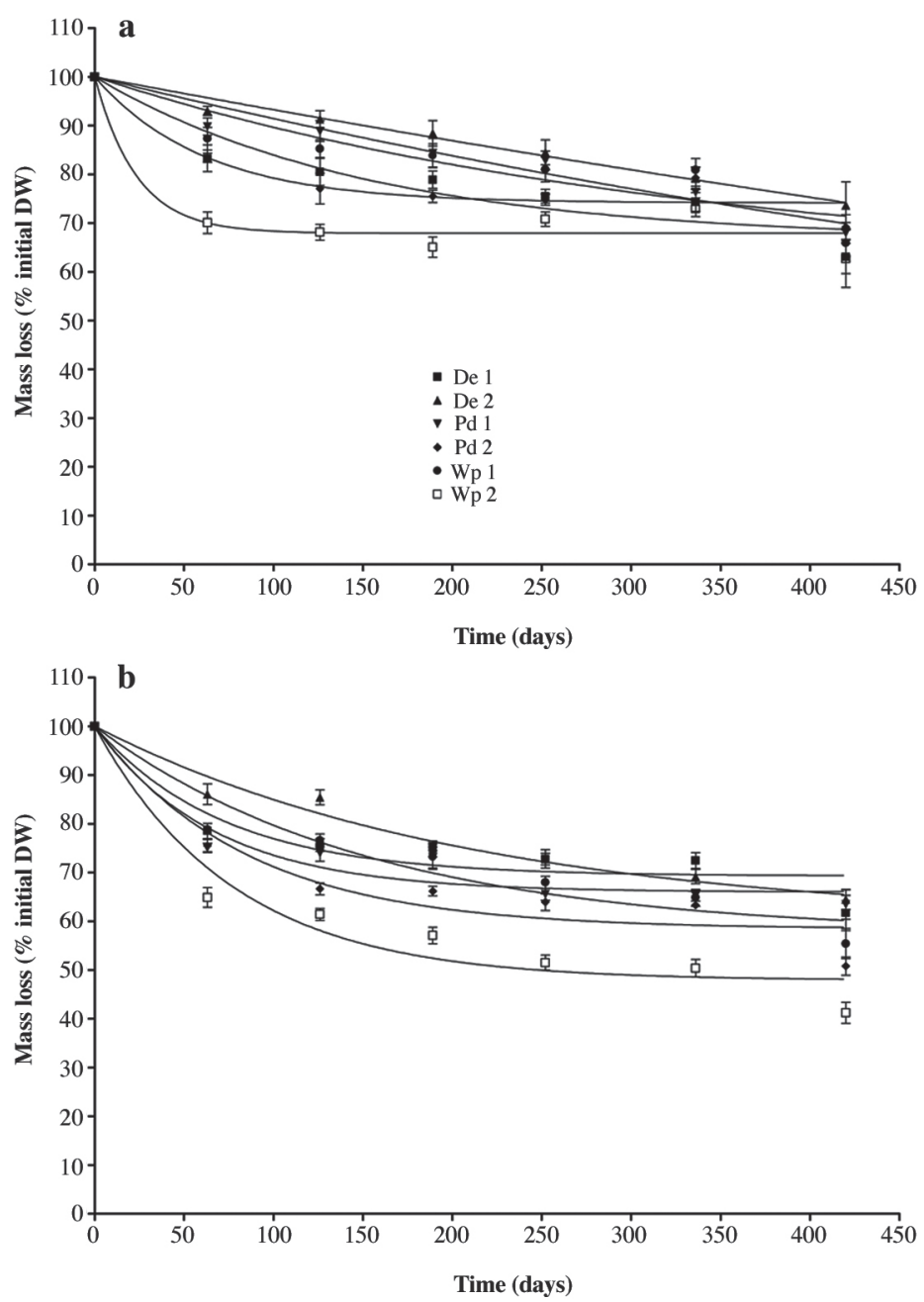

Figure 1. Weight loss as a percentage of initial weight for Acacia caven and Lolium multiflorum in a degraded ecosystem (De), typical ecosystem (Pd), and well preserved ecosystem (Wp). Vertical bars indicate standard deviation; $n=10$; $(\mathbf{p}<\mathbf{0 . 0 5})$.

et al., 2003), dynamics also observed in $\mathrm{PC} 2$ for $\mathrm{N}$ and $\mathrm{C} / \mathrm{N}$ ratio (Table 3). The content of $\mathrm{P}$, hemicellulose, and lignin did not show high correlations with the rest of the variables.

The influence of ecosystems (E), time (T), and their interaction $(\mathrm{E} \times \mathrm{T})$ during the decomposition process with the study variables was evaluated by ANOVA for each principal component (PC1, PC2, and PC3). Analysis detected significant differences for $\mathrm{E}, \mathrm{T}$, and their interaction $(\mathrm{p}<0.01)$ for the PC1 and PC 3 components. The Wp ecosystem exhibited the transformation of chemical components for PC1 (Figure 3a) in the initial phase (0-120 d) and at the end of the decomposition process (330-420 d). On the other hand, Pd and De ecosystems exhibited component transformations into the final period (250 and $330 \mathrm{~d}$, respectively). Transformations in PC3 (Figure 3b) plant material were more marked and similar for the three ecosystems in the initial phase (0-120 d) of the decomposition process; Pd showed dynamics distinct from the other ecosystems in the rest of the period. Analysis for PC2 produced significance for $\mathrm{E}$ and $\mathrm{T}$, but not for their interaction (E x T) which is mainly associated to $\mathrm{N}$ content $(\mathrm{r}=0.91)$ and indicated a significant increase (Figure 4) of this nutrient $60 \mathrm{~d}$ after the material was incubated in the field.

Lolium multiflorum. Principal component analysis determined that the first two components (PC1 and PC2) explained 50\% and when third (PC3) was included, it increased to $80 \%$ (Table 3 ). The higher positive correlations for PC1 were for weight loss ( $\mathrm{r}$ $=0.84), \mathrm{N}(\mathrm{r}=0.82)$, ash $(\mathrm{r}=0.81)$, lignin $(\mathrm{r}=0.79)$, and non-structural components $(\mathrm{r}=0.53)$, whereas negative correlations were observed for the $\mathrm{C} / \mathrm{N}$ ratio 
Table 3. Correlation matrix of principal components for Acacia caven and Lolium multiflorum.

\begin{tabular}{lccccccc}
\hline & \multicolumn{3}{c}{ Acacia caven } & & \multicolumn{3}{c}{ Lolium multiflorum } \\
\cline { 2 - 3 } \cline { 6 - 7 } Variables & PC1 & PC2 & PC3 & & PC1 & PC2 & PC3 \\
\hline Weight loss & -0.51 & 0.52 & -0.23 & & 0.84 & 0.32 & 0.04 \\
Fiber and other fractions & & & & & & & \\
Cellulose & 0.78 & -0.02 & -0.18 & -0.75 & 0.56 & 0.22 \\
Hemicellulose & 0.29 & 0.10 & -0.32 & & 0.00 & -0.45 & 0.82 \\
Lignin & 0.26 & 0.27 & -0.55 & & 0.79 & 0.31 & 0.17 \\
Non-structural components & -0.73 & -0.21 & 0.61 & & 0.53 & -0.48 & -0.69 \\
Nutrient concentration & & & & & & \\
Nitrogen & 0.16 & 0.91 & 0.17 & & 0.81 & -0.48 & 0.14 \\
Carbon & 0.75 & 0.36 & 0.43 & & 0.82 & 0.50 & -0.08 \\
C/N Ratio & 0.67 & -0.55 & 0.34 & -0.74 & 0.24 & -0.32 \\
Phosphorus & -0.35 & 0.53 & 0.42 & -0.91 & -0.30 & -0.11 \\
Ash & -0.76 & -0.22 & -0.35 & & 0.38 & 0.13 & -0.06 \\
\hline
\end{tabular}

PC1: first principal component; PC2: second principal component; PC3: third principal component.

$(\mathrm{r}=-0.91)$, cellulose $(\mathrm{r}=-0.75)$, and $\% \mathrm{C}(\mathrm{r}=-0.74)$. These results would indicate that there was a significant increase in weight loss associated with ash content and an important degradation of structural material such as cellulose (also expressed as \%C), as well as a decrease in the $\mathrm{C} / \mathrm{N}$ ratio during the decomposition period. The main structural constituent for this litter was cellulose (37\%) (Table 1). Magid et al. (2004) reported that materials with a high concentration of non-structural components and low lignin content showed a rapid decrease in cellulose content and greater decomposition, fact corroborated by

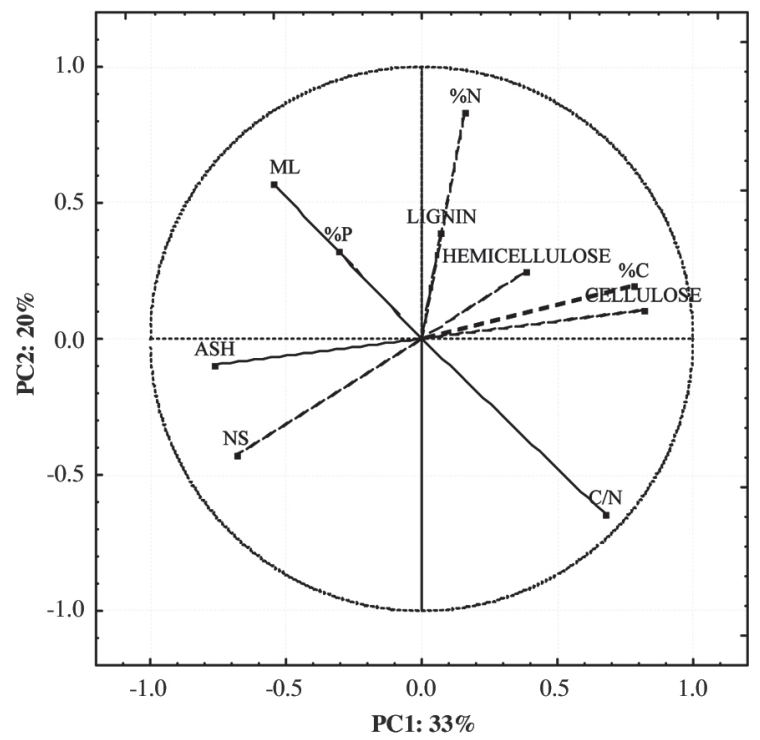

Figure 2. Two-dimensional graph for PC1 and PC2 of Acacia caven litter with the variables under study. ML: mass loss.
Fioretto et al. (2005) when they observed that materials with a cellulose concentration similar to L. multiflorum in this study, but with a higher lignin $(18 \%)$ concentration, exhibited a more rapid initial decomposition (0 to $250 \mathrm{~d}$ ) which steadily declined up to $18 \mathrm{~m}$. With a lower lignin (7\%) concentration in our study, we observed that most of the variables exhibited transformation of chemical composition, process that could be associated during the first months of incubation to precipitation in the winter months affecting lixiviation of the most soluble chemical constituents (Trofymow et al., 2002; Vávřová et al., 2009).

As for A. caven, there was an increase in $\mathrm{N}(\mathrm{PC} 1, \mathrm{r}=$ 0.82 ) during the decomposition period of L. multiflorum which is explained by the loss of $\mathrm{C}-\mathrm{CO}_{2}$ associated with the metabolism of soil microorganisms while $\mathrm{N}$ (organic) concentration increases in the residual material (Berg and Laskowski, 2006). The high positive correlation in lignin content $(r=0.79$; Table 3$)$ shows the most active role of this fraction and a greater concentration in the residual material, typical of the recalcitrant phase of the decomposition process which slightly influences the increase of material decomposition velocity in more advanced decomposition stages.

The variance ratio explained by PC2 was $16 \%$ and had a greater correlation with cellulose $(\mathrm{r}=$ 0.56), whereas PC3 was $14 \%$ with a high positive correlation for hemicellulose $(\mathrm{r}=0.82)$ and a negative correlation for non-structural components $(r=-0.69)$. Hemicellulose in this litter was the second constituent with the highest concentration, $31 \%$ content (Table 1), which coincides with results obtained by Luxhøi et al. (2002) in distinct species with values fluctuating between 16 and $41 \%$. It is difficult to degrade both 

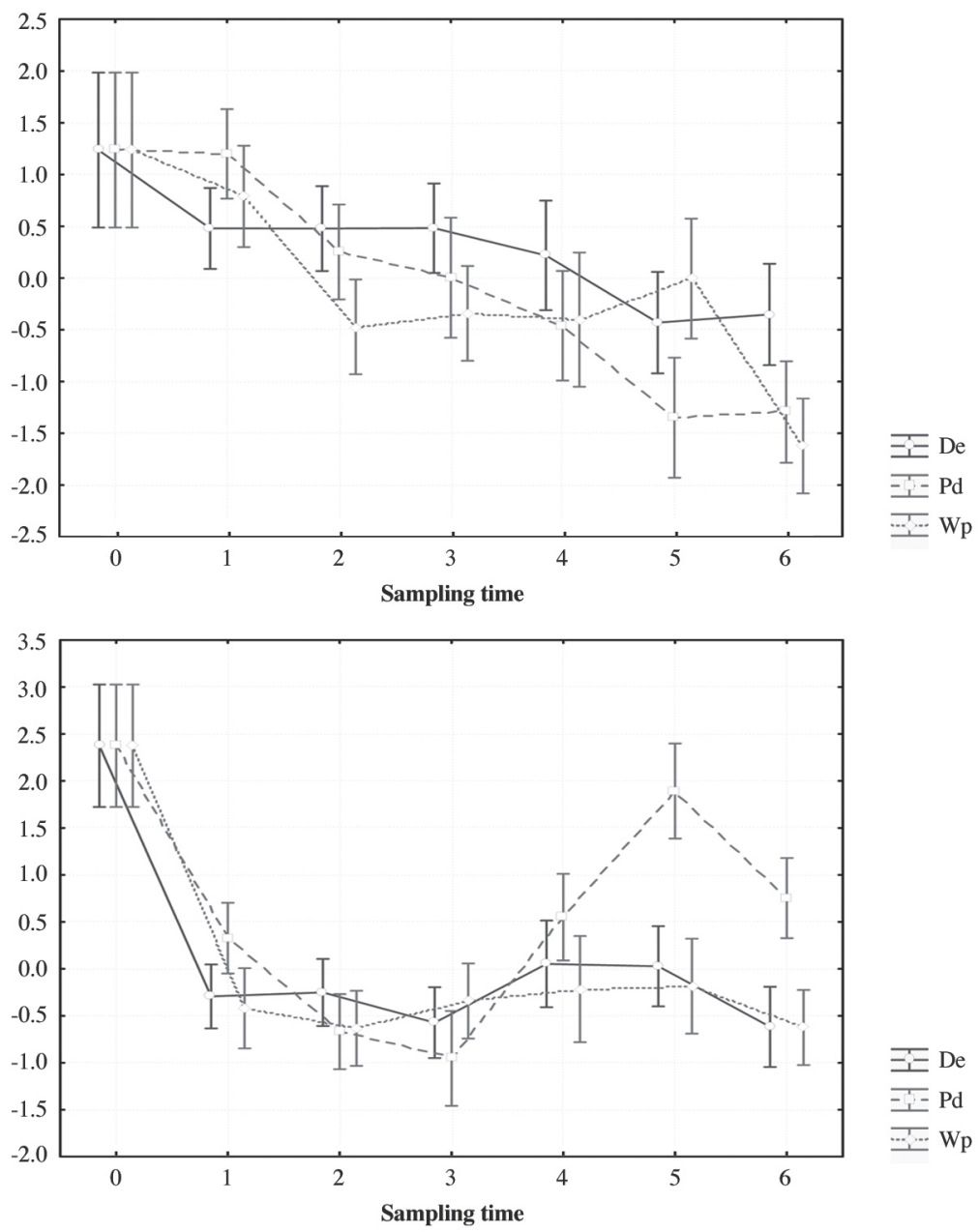

Figure. 3. ANOVA (p < 0.001) for PC1 (a) and PC3 (b) factors for Acacia caven. De = degraded, Pd = typical, and Wp $=$ well preserved. Time $0=$ initial stage of material. Time $1,2,3,4,5$, and $6=60,120,180,250,330$, and $420 \mathrm{~d}$, respectively.

hemicellulose and lignin; however, the lignin fraction appears as the principal recalcitrant component controlling the decomposition process after the initial phase. Figure 5 shows the results for PC1 and PC2 where most of the observations were accumulated in the axes extremes for the first component, though hemicellulose stands out for its distinct value and is not correlated with PC1 or negatively correlated with PC2. Observations for the second component were concentrated in the central axis, thus demonstrating a low correlation between variables.

\section{Influence of chemical composition and ecosystems on decomposition}

During the decomposition process, A. caven was controlled by non-structural component degradation in the labile phase, by cellulose content, and to a lesser degree, lignin in the recalcitrant phase (Table 3). Both high $\mathrm{N}$ content and high $\mathrm{C} / \mathrm{N}$ ratio suggest influence in the initial decomposition phase although a high lignin concentration (Table 1) could be related to a large proportion of recalcitrant $\mathrm{N}$ (Berg, 1986). The labile phase for $L$. multiflorum was controlled by cellulose degradation, by lignin, and to a lesser degree, hemicellulose in the recalcitrant phase (Table 3), results coinciding with those found by Magid et al. (2004).

The first decomposition phase took place during the rainy months, indicating that it was regulated for climatic conditions and a decrease in decomposition velocity during the dry season for both species (Figure 1). The alternation of wet and dry seasons in Mediterranean zones is what most influences biological activity and litter decomposition (Fioretto et al., 2007). Other authors conclude that litter decomposition is selective and would be linked to the quality of the substrate (Coûteaux et al., 1995). Canopy cover in Mediterranean conditions has a positive effect on litter decomposition (García-Pausas et al., 2004; Su et al., 2004). 


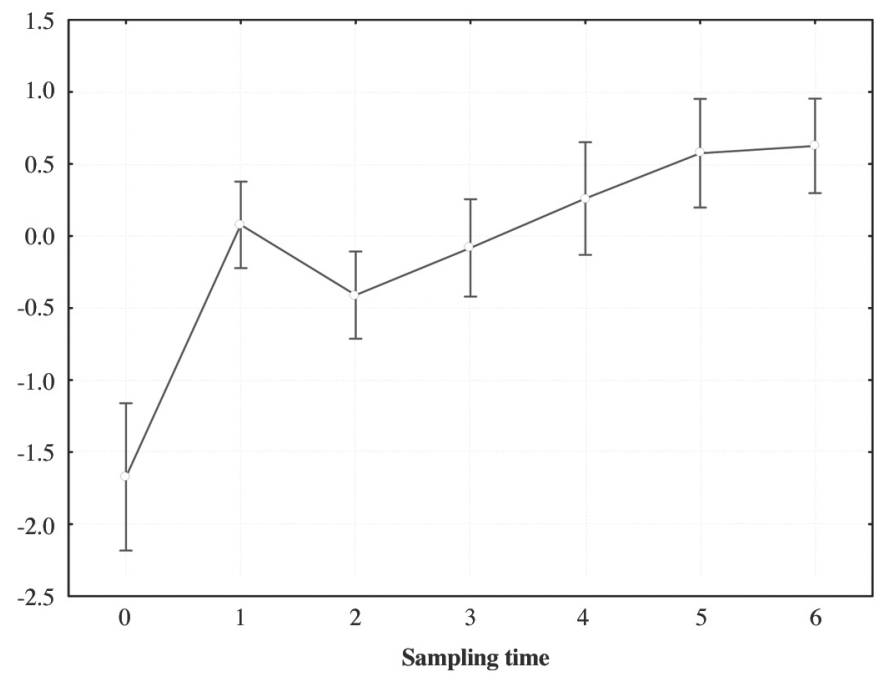

Figure 4. ANOVA ( $\mathrm{p}<0.001$ ) PC2 factor for Acacia caven. Time $0=$ material in initial stage. Time 1, 2, 3, 4, 5, $6=60$, $120,180,250,330$, and $420 \mathrm{~d}$, respectively.

Microenvironmental conditions in well preserved ecosystems increase nutrient concentration as compared to ecosystems that are degraded or surrounded by bare areas (Ovalle and Avendaño, 1988; Carrera et al., 2009; Ovalle et al., 2006). An ecosystem with greater canopy cover decreases element loss, protecting nutrients liberated in the decomposition (Babbar and Ewel, 1989) so that the combination of litter chemical characteristics and the degree of cover had a positive influence on the chemical and physical transformations of each material.

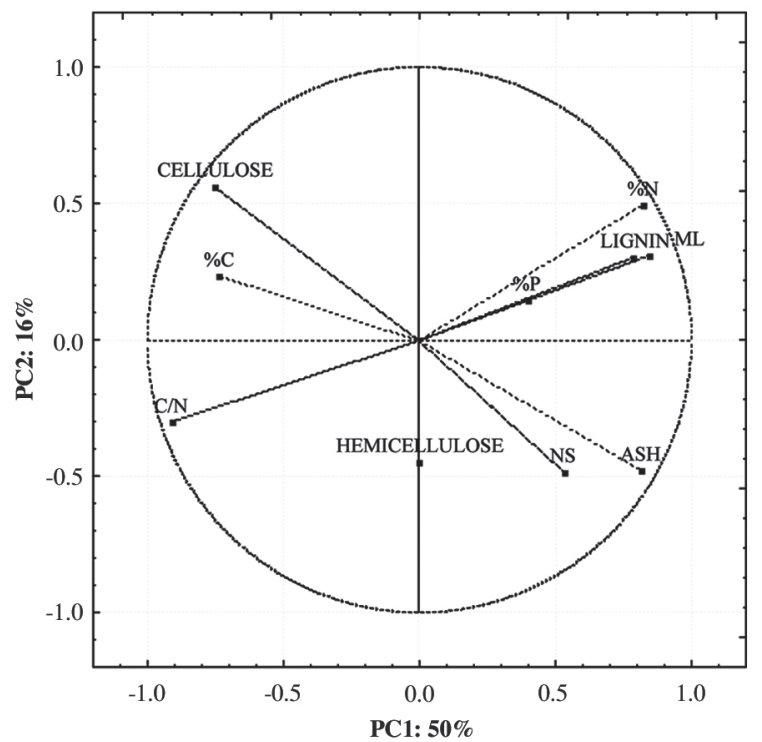

Figure 5. Two-dimensional graph for Lolium multiflorum, correlations of PC1 and PC2 principal components with each variable under study.
Dynamics similar to those reported in this study suggest that water in the soil and climate are relevant factors in the transformation of chemical constituents during litter decomposition (McTiernan, 2003). These factors also have an influence on landscape heterogeneity and on characteristics such as $\mathrm{OM}, \mathrm{N}$, and $\mathrm{P}$ as a consequence of the direct relationship between aerial biomass, canopy cover, and the generated microclimate, all of which would also contribute to soil fertility (Ovalle and Avendaño, 1988; Ovalle et al., 2006; Muñoz et al., 2007b).

\section{CONCLUSIONS}

Decomposition of organic material in espinal ecosystems in Mediterranean Chile was influenced by the material chemical composition. Lolium multiflorum had a higher weight loss during the study period and the decomposition process was controlled by cellulose degradation in the labile phase, by lignin, and to a lesser extent, by hemicellulose in the recalcitrant phase. On the other hand, for A. caven, decomposition in the labile phase was controlled by nonstructural component degradation, by cellulose, and to a lesser degree, by lignin content in the recalcitrant phase. Canopy cover showed a positive effect on decomposition. The highest decomposition velocity coincided with the rainy period, whereas the lowest velocity occurred during the dry season. Better knowledge of the dynamics of plant material decomposition in ecosystems was achieved through the complementary use of the two techniques applied: quantification of weight loss with litter and quantification of chemical transformations of material by NIRS. 


\section{ACKNOWLEDGEMENTS}

Research was financed by FONDECYT (Project $\mathrm{N}^{\circ}$ 1030883), and by the Instituto de Investigaciones Agropecuarias INIA, Cauquenes Experimental Centre for its contribution of study sites, as well as support staff. The authors acknowledge the contribution of the Teresa Aravena, an agricultural technician, and the Centre National de la Recherche Scientifique, Centre d'Ecologie Fonctionnelle et Evolutive (CEFE-CNRS) in France for the stay of I. Martínez in that country, for NIRS, and Van Soest analysis.

\section{RESUMEN}

Descomposición de hojarascas de Acacia caven (Molina) Molina y Lolium multiflorum Lam. en ecosistemas de clima mediterráneo. Los ecosistemas del secano interior mediterráneo de Chile presentan una baja productividad debido a la degradación de los suelos, dominados por un agroecosistema espinal de Acacia caven (Molina) Molina. El objetivo de este estudio fue evaluar la descomposición de hojarascas de A. caven y Lolium multiflorum Lam., en ecosistemas espinales: densos (Wp) con cobertura de $50-80 \%$, poco densos (Pd) $25-50 \%$ y degradados (De) $10-25 \%$. Se determinó la pérdida de peso usando bolsas de malla, durante 420 días comenzando en abril de 2004, y la composición química del material: hemicelulosa, celulosa, lignina, componentes no estructurales, cenizas, $\mathrm{N}, \mathrm{C}$, relación $\mathrm{C} / \mathrm{N}$ y $\mathrm{P}$; usando espectroscopía de reflectancia en el infrarrojo cercano (NIRS). Los resultados indicaron que la pérdida de peso fue mayor en L. multiflorum (31-52\%) que en A. caven (26-40\%). La descomposición del material estuvo influenciada por su composición química, en L. multiflorum gobernada en su fase lábil por la degradación de celulosa y en su fase recalcitrante por lignina; en cambio en $A$. caven por los componentes no estructurales y celulosa en su fase lábil, y en su fase recalcitrante por lignina. Debido a la descomposición ambos materiales incrementaron su concentración de N. Los ecosistemas espinales de mayor cobertura de árboles (De y Pd) tuvieron una influencia positiva, mostrando una descomposición más temprana, especialmente en el ecosistema De, probablemente por las condiciones microambientales generadas. Un mejor conocimiento de la dinámica de descomposición de hojarascas en los ecosistemas, se logró a través del uso de las dos técnicas usadas.

Palabras clave: cobertura de árboles, pérdida de peso, bolsas de malla, NIRS, componentes principales.

\section{LITERATURE CITED}

Aronson, J., C. Ovalle, J. Avendaño, L. Longeri, and A. Del Pozo. 2002. Agroforestry tree selection in central Chile: biological nitrogen fixation and early plant growth in six dryland species. Agroforestry Systems 56:155-166.

Babbar, L., y J. Ewel. 1989. Descomposición del follaje en diversos ecosistemas sucesionales tropicales. Biotropica 21:20-29.

Berg, B. 1986. The influence of experimental acidification on nutrient release and decomposition rates of needle and root litter in the forest floor. Forest Ecology and Management 15:195-213.

Berg, B., and R. Laskowski. 2006. Advances in ecological research. Litter decomposition: A guide to carbon and nutrient turnover. 421 p. Vol. 38. Elsevier Academic Press, San Diego, California, USA.

Bernhard-Reversat, F. 1999. Changes in relationships between initial litter quality and $\mathrm{CO}_{2}$ release during early laboratory decomposition of tropical leaf litters. European Journal of Soil Biology 34:117-122.

Carrera, A.L., M.J. Mazzarino, M.B Bertiller, H.F. del Valle, and E.M. Carretero. 2009. Plant impacts on nitrogen and carbon cycling in the Monte phytogeographical Province, Argentina. Journal of Arid Environments 73:192-201.

CIREN. 1994. Estudio agrológico. VII Región. Descripciones de suelos, materiales y símbolos. Publicación N ${ }^{\circ} 117.660$ p. Centro de Información de Recursos Naturales (CIREN), Santiago, Chile.

Coûteaux, M.M., P. Bottner, and B. Berg. 1995. Litter decomposition, climate and litter quality. Tree 10:6366.

Coûteaux, M.M., D. Hervé, and S. Beck. 2006. Decomposition of plant litter and roots in a long fallow system (Bolivian Altiplano). Ecología en Bolivia 41:85-102.

Coûteaux, M.M., K.B. McTiernan, B. Berg, D. Szuberla, P. Dardene, and P. Bottner. 1998. Chemical composition and carbon mineralization potential of Scots pine needles at different stages of decomposition. Soil Biology \& Biochemistry 30:583-595.

Coûteaux, M.M., L. Sarmiento, D. Hervé, and D. Acevedo. 2005. Determination of water-soluble and total extractable polyphenolics in biomass, necromass and decomposing plant material using near-infrared reflectance spectroscopy (NIRS). Soil Biology \& Biochemistry 37:795-799.

Dalias, P., J.M. Anderson, P. Bottner, and M.M. Coûteaux. 2001. Long-term effects of temperature on carbon mineralisation processes. Soil Biology \& Biochemistry 33:1049-1057. 
Del Pozo, A., y P. Del Canto. 1999. Áreas agroclimáticas y sistemas productivos en la VII y VIII Regiones. Instituto de Investigaciones Agropecuarias (INIA), Centro Regional de Investigación Quilamapu, Chillán, Chile.

Fioretto, A., C. Di Nardo, S. Papa, and A. Fuggi. 2005. Lignin and cellulose degradation and nitrogen dynamics during decomposition of three leaf litter species in a Mediterranean ecosystem. Soil Biology \& Biochemistry 37:1083-1091.

Fioretto, A., S. Papa, and A. Fuggi. 2003. Litter-fall and litter decomposition in a low Mediterranean shrubland. Biology and Fertility of Soils 39:37-44.

Fioretto, A., S. Papa, A. Pellegrino, and A. Fuggi. 2007. Decomposition dynamics of Myrtus communis and Quercus ilex leaf litter: Mass loss, microbial activity and quality change. Applied Soil Ecology 36:32-40.

García-Pausas, J., P. Casals, and J. Romanya. 2004. Litter decomposition and faunal activity in Mediterranean forest soil: Effects of $\mathrm{N}$ content and the moss layer. Soil Biology \& Biochemistry 36:989-997.

Gillon, D., F. Dauriac, M. Deshayes, J.C. Valette, and C. Moro. 2004. Estimation of foliage moisture content using near infrared reflectance spectroscopy. Agricultural and Forest Meteorology 124:51-62.

Kim, C., T.L. Sharik, and M.F. Jurgensen. 1996. Canopy cover effects on mass loss and nitrogen and phosphorus dynamics from decomposing litter in oak and pine stands in northern Lower Michigan. Forest Ecology and Management 80:13-20.

Luxhøi, J., J. Magid, D. Tscherko, and E. Kandeler. 2002. Dynamics of invertase, xylanase and coupled quality indices of decomposing green and brown plant residues. Soil Biology \& Biochemistry 34:501-508.

Magid, J., J. Luxhøi, and O. Lyshede. 2004. Decomposition of plant residues at low temperatures separates turnover of nitrogen and energy rich components in time. Plant and Soil 258:351-365.

Martínez-Yrízar, A., S. Núñez, and A. Búrquez. 2007. Leaf litter decomposition in a southern Sonoran Desert ecosystem, northwestern Mexico: Effects of habitat and litter quality. Acta Oecologica 32:291-300.

McTiernan, K., M. Coûteaux, B. Berg, M. Berg, R. Calvo de Anta, A. Gallardo, et al. 2003. Changes in chemical composition of Pinus sylvestris needle litter during decomposition along a European coniferous forest climatic transect. Soil Biology \& Biochemistry 35:801-812.

Melillo, J.M., J.D. Aber, A.E. Linkins, A. Ricca, B. Fry, and K.J. Nadelhoffer. 1989. Carbon and nitrogen dynamics along the decay continuum: plant litter to soil organic matter. Plant and Soil 115:189-198.
Muñoz, C., E. Zagal, and C. Ovalle. 2007a. Distribution of soil organic carbon stock in an Alfisol profile in Mediterranean Chilean ecosystems. Revista de la Ciencia del Suelo y Nutrición Vegetal 7:15-27.

Muñoz, C., E. Zagal, and C. Ovalle. 2007b. Influence of trees on soil organic matter in Mediterranean agroforestry systems: an example from the Espinal of central Chile. European Journal of Soil Science 58:728-735.

Ovalle C., A. Aronson, A. Del Pozo, and J. Avendaño. 1990. The espinal: agroforestry systems of the Mediterraneantype climate region of Chile. Agroforestry Systems 10:213-239.

Ovalle, C., e J. Avendaño. 1988. Interactions de la strate ligneuse avec le strate herbacée dans les formations d'Acacia caven (Mol.) Hook et Am. au Chili. II. Influence de l'arbre sur quelques elements du milieu microclimatic et sol. Oecologia Plantarum 9:113-134.

Ovalle, C., A. Del Pozo, M. Casado, B. Acosta, and J.M. de Miguel. 2006. Consequences of landscape heterogeneity on grassland diversity and productivity in the Espinal agroforestry system of central Chile. Landscape Ecology 21:585-594.

Reichstein, M., J.D. Tenhunen, O. Roupsard, J.M. Ourcival, S. Rambal, S. Dore, and R. Valentini. 2002. Ecosystem respiration in two Mediterranean evergreen Holm Oak forests: drought effects and decomposition dynamics. Functional Ecology 16:27-39.

Ritter, E., and L. Bjørnlund. 2005. Nitrogen availability and nematode populations in soil and litter gap formation in a semi-natural beech-dominated forest. Applied Soil Ecology 28:175-189.

Sadzawka, A., M.A. Carrasco, R. Grez, M.L. Mora, H. Flores, y A. Neaman. 2006. Métodos de análisis recomendados para los suelos de Chile. Revisión 2006. Serie Actas INIA $\mathrm{N}^{\circ}$ 34. Instituto de Investigaciones Agropecuarias, Santiago, Chile.

Schimann, H., R. Joffre, J.C. Roggy, R. Lensi, and A.M. Domenach. 2007. Evaluation of the recovery of microbial functions during soil restoration using nearinfrared spectroscopy. Applied Soil Ecology 37:223232.

Stat Soft. 2000. STATISTICA for Windows. Stat Soft, Tulsa, Oklahoma, USA.

Stolpe, N.B. 2006. Descripción de los principales suelos de la VIII Región de Chile. Universidad de Concepción, Facultad de Agronomía, Departamento de Suelos y Recursos Naturales, Chillán, Chile.

Su, Y., H. Zhao, Y. Li, and H. Cui. 2004. Carbon mineralization potential in soils of different habitats in the semiarid horquin sandy land: a laboratory experiment. Arid Land Research and Management 18:39-50. 
Trofymow, J.A., T.R. Moore, B. Titus, C. Prescott, I. Morrison, M. Siltanen, et al. 2002. Rates of litter decomposition over 6 years in Canadian forests: influence of litter quality and climate. Canadian Journal of Forest Research 32:789-804.

van Meeteren, M.J.M., A. Tietema, E.E. van Loon, and J.M. Verstraten. 2008. Microbial dynamics and litter decomposition under a changed climate in a Dutch heathland. Applied Soil Ecology 38:119-127.

Van Soest, P.J., and J.B. Robertson. 1985. Analysis of forage and fibrous foods: A laboratory manual for animal science. 613 p. Cornell University, Ithaca, New York, USA.
Vávřová, P., T. Pentilä, and R. Laiho. 2009. Decomposition of Scots pine fine woody debris in boreal conditions: Implications for estimating carbon pools and fluxes. Forest Ecology and Management 257:401-412.

Verdoodt, A., S. Mureithi, L. Ye, and E. Van Ranst. 2009. Chronosequence analysis of two enclosure management strategies in degraded rangeland of semiarid Kenya. Agriculture Ecosystems \& Environment 129:332-339. 